\title{
Socially Productive Activities and Subjective Wellbeing Among Rural Perak Elderly
}

\author{
Nur Syakirah Hamzah", Ramlee Ismail ${ }^{2}$ \\ ${ }^{1,2}$ Fakulti Pengurusan dan Ekonomi, \\ Universiti Pendidikan Sultan Idris, Malaysia \\ shakirahamzah90@gmail.com \\ DOI: https://doi.org/10.37134/jcit.vol8.6.2018
}

\begin{abstract}
The uncertain knowledge on level of wellbeing among older adults has attracted an increasing number of public, political and scientific attentions. Wellbeing has been described as a state of equilibrium or balance that can be affected by life events or challenges. The purpose of this study is to investigate the relationship between socially productive activities and subjective wellbeing among rural elderly in Perak. A descriptive research methodology was adopted for this research. A broad range of productive factors (such as voluntarism and paid work) and measures of wellbeing (such as self-rated health and life satisfaction) shall be analysing in t-test and Pearson correlation analysis. Information needed are obtained sing a cross-sectional design method across rural districts in Perak. Questionnaires survey was distributed to 480 older adults age from 50 t0 75+. This paper found out that there are no significant different between paid work and self-rated health and life satisfaction, whereas there are significant relationship between voluntarism and self-rated health and life satisfaction. The result from this research shall provide provision for the idea that engaging in voluntarism is advantageous to elderly well-being.
\end{abstract}

Keywords: Aging population, subjective wellbeing, socially productive activities

\section{INTRODUCTION}

The world population is ageing. This is because the world's older population continues to grow at a remarkable rate. Birth rates are decreasing but people are living longer. In the next century, the number of people age 60 and above set more than double, climbing from 7.2 billion in 2015 to 20 billion in 2050 (WHO, 2015). For the first time in history, there will be more over 60 than under 15 (Haub, 2011). This information suggests that the elderly will soon become a major population on society. The challenge, however, is finding ways that turn the elderly into an asset by seeing them as sources of innovation.

As a developing country, Malaysia is no exception. Economic Planning published Malaysian Wellbeing Index 2013 to study this matter. One of the components, namely, social participation is also measured. In Malaysia Wellbeing Index 2013, social participation is elaborated as the sense of generality that was essential towards improving human wellbeing. It is the ability to be involved and contribute to a bigger society in the sense of freedom of life (Bakar, Osman, Bachok, \& Ibrahim, 2016). This research differs from other by taking paid work and voluntarism as the socially productive activities. Paid work is generally an employment or attachment with company in a way that the individual productivity would be converted into monetary benefits. Voluntarism, in the other hand, is an act of performing productive activities with no monetary benefits. Both productive activities shall be evaluated by the combination of physical activity, mental activity, and social activity as well as physical function (Shah, Lin, Yu, \& McMahon, 
2016). The purpose of this research is to investigate the relationship between voluntarism and life satisfaction. Specifically, the researcher wants to analyse the activity of voluntarism in which the person involve to determine the level of life satisfaction.

\section{LITERATURE REVIEW}

\section{Employment Status and Life satisfaction}

Some says being busy is the secret of happiness. It creates senses of purpose because brains and body will have the drive to fulfil the goal (Sone et al., 2008) Human perform these many types of activities in order to attain optimal level of wellbeing. Be it monetary, physical, and emotional as well as social aspects. Wellbeing has been described as a state of equilibrium or balance that can be affected by life events or challenges (Dodge, Daly, Huyton, \& Sanders, 2012). In general, wellbeing is perceived to be a macro concept or area of study concerned with the objective and subjective assessment of wellbeing as a desirable human state (McNaught, 2011). This definition later investigates by adding on that wellbeing is measured beyond individual subjectivity. Wellbeing then are classified into 2 categories; objective and subjective (Alatartseva \& Barysheva, 2015). Objectives wellbeing is based on the approach which allows evaluating the degree of basic human needs satisfaction such as food and housing. On the other hand, subjective wellbeing is oneself perception towards the condition they experience such as quality of life and evaluation of physical body (Sarracino, 2010). Relationship between productivity and well-being has always been an argument over past decade. Several studies have shown a link between productive activities and wellbeing among aging population. Based on previous literatures, researcher presumed that socially productive activities shall give advantages to elderly subjective wellbeing. Researcher also suggests that being employed at third age may influence life satisfaction and lead to optimum health level. These assumptions are created based on previous study. There is rapidly growing literature on the relationship between paid work and life satisfaction of elderly after retirement age. In a current study conducted by (Akintayo, Häkälä, Ropponen, Paronen, \& Rissanen, 2016), well-being of elderly is more closely related to paid work than to non-paid work. Elderly are expected to experience happiness when they are employed. It has been found out that in Hong Kong even though social participation is important for the elderly, civic participation and employment was significantly associated with the old-old group only (Au et al., 2017).

\section{Employment Status and Self-rated Health}

On the basis of the evidence currently available, it seems fair to suggest that working after retirement age benefits the elderly by supporting healthy aging. Elderly who works regularly did not show any evidence of negative mental health. This study showed that post-retirement working has a statistically significant positive effect on a range of mental health outcomes (Maimaris, Hogan, \& Lock, 2010). It has become a global trend with ensuing changes in labour markets around the world. Increased attention is paid to investigating the effects of the timing of retirement around the world and the macroeconomic benefits that often associated with delaying retirement (Staudinger, 
Finkelstein, Calvo, \& Sivaramakrishnan, 2016). There is evidence showing a positive relationship between working elderly and health. The strength of associations between social participation and positive self- rated health, loneliness, and life dissatisfaction is influenced by the number of different types of frequent social activities. The study also shows that senior women are interested in social activities compare to senior men (Gilmour, 2012).A study by Brunel University in London, shows how, in the past, research into understanding wellbeing was mainly concerned with monetary factor.

Although financial reward was acknowledged to increase wellbeing, further discussion shall be notable especially on the type of work that can or influence health and lead to improvement of personal development. There is overwhelming evidence for the notion shows that conversion into retirement lead to deceasing in physical health. A study in Korea was conducted by mediating both monetary and non-monetary factor. Elderly whom engage in justifiable employment score highest in elf-rated health. Along similar lines, other employment statuses that contribute to subjective poor physical health are reported on elderly include being unpaid family workers, self-employ and precarious workers (Lee \& Kim, 2017). Although some research has been carried out on positive relationship between working beyond retirement age with health, there has been empirical investigation contrast to this. Type of productive activities also influences wellbeing. Elderly who's working in care giving centre reported to have low level of wellbeing. This relationship was facilitated by perceived time adequacy, income adequacy, and sense of community, such that the more time participants spent care giving, the lower their ratings of these three resources. This explained the initial association of care giving hours with reduced well-being (Hilbrecht, Lero, Schryer, Mock, \& Smale, 2017). Voluntary or involuntary retirement increased the risk of depressive symptoms in elderly population. Furthermore, it also has effects on relationship between elderly husband and wife. Husbands' voluntary retirement increased wives' risk of depressive symptoms (Kim, Park, \& Antonucci, 2016). Paid work participation declined linearly with age and health status, but this relationship did not hold for other activities (Sabbath et al., 2016).

\section{Voluntarism and Life Satisfaction}

There is no clear statistic as how many Malaysian elderly involve in voluntarism activities. The little exposure about the benefits of these activities might become the reason on why only few Malaysian elderly involving themselves. According to Sabbath et al. (2016), men are more active in volunteering and community activities, whereas women are into care giving and informal social interaction. Even though this gender demographic factor varies, both are happy when performing productive work. This is consistence Zhang, Feng, Lacanienta, and Zhen (2017) studies that conclude, productive and social activities are beneficial for both gender. Females elderly are more likely to occupy their free time in societal and arts activities, whereas, males prefer visual activities as well as activities that detach them away from the work situation. Social interaction is a crucial aspect in productive activities. The lack of social connectedness is a key reason for life dissatisfaction among large proportion of the elderly in Russia. A research has found bilateral correlation between subjective life satisfaction and willingness to help other people. Happier elderly people are more likely to help even outside families. People providing help are more likely 
to be happier in general compared to those who do not (Malanina, Frolova, \& Lei, 2017). Research by Baker, Cahalin, Gerst, and Burr (2005) show as time committed to voluntarism activities increases, life satisfaction increases. Both increasing numbers of voluntarism activities and increasing time commitment predict higher levels of happiness.

This study also finds modest support for a relationship between productive activities and the number of and changes in depressive symptoms. Previous research has indicated that various voluntarism indicators have a positive impact on life satisfaction (McMunn, Nazroo, Wahrendorf, Breeze, \& Zaninotto, 2009). Voluntarism is an act of willingness to act in or share your expertise such as involvement in community, political party, non-government organisation, taking care of others and many more. Those actions were done without hoping for material rewards (Nawi, Asmuni, \& Pendidikan, 2013). Data show that a psychological sense of community has a key role in the study of older volunteerism due to its impact on well-being. Service agencies and administrations can develop campaigns to sustain older volunteerism in order to increase well-being and reduce social costs (Pozzi, Marta, Marzana, Gozzoli, \& Ruggieri, 2014). In another major study, it has been found that there is relationship between degree of satisfaction with the management and the intention of remaining in service. The degree of satisfaction with management has shown to be an important predictor of older volunteers' intention of remaining in service. These findings have important implications on how organisations manage volunteerism and the relationship between paid staff and volunteers (Ruiz, Marcos-Matás, \& Tornero, 2016). Known the nature of leisure as 'not forced' and unnecessary for survival, it seems apparent that leisure activities ought to contribute happiness. Indeed, recent research has found positive effects of leisure activities on subjective well-being. These results indicate that meeting with friends, doing sports, and going on vacation gives positive impact on life satisfaction (Schmiedeberg \& Schröder, 2017).

\section{Voluntarism and Self-rated Health}

Along with monetary benefits, emotional and physical benefits have been found to correlate with volunteering among the elderly. Herzog, House, \& Morgan (1991) suggest that by involving themselves in voluntarism activities, it shall benefit them towards health vitality. In addition to that, elderly would experience enhanced psychological well-being (VanWilligen, 2000). It will also improve self-esteem (Thoits \& Hewitt, 2001) and benefits in term of lengthen the age of elderly (Musick, Herzog, \& House, 1999; Oman, Thoresen, \& McMahon, 1999) and improved social skills (Mutchler, Burr, \& Caro, 2003). According to institute of Volunteering Research of Canada, in order to maintain the sense of purpose and self-respect, voluntary work can fill up the gap of feeling unwanted due to retirement from paid work to feeling of achieving intended goal. It will then lessen the isolation felt by those whom detach from the social networks into the workplace and from their families. It also has beneficial effects on physical and mental health. 


\section{METHODOLOGY}

A descriptive research methodology was adopted for this research. Perak rural area is chosen as a population location. Perak is the third biggest aging population states. Specifically, aging population in rural area is selected due to its higher aging population compared to urban area. Malay and Bumiputera race is selected as it is the largest race in Malaysia. In addition, financial and time constrain contribute as reasons for researcher to use Perak as research location. A total of 480 respondents from aging population aged between 50 to $75+$ years old are drawn from a total of 126,469. This research employs nonprobability sampling method in selecting respondent to make up the sample.

\section{FINDINGS}

Table 1: Data Distribution of Respondent Respondent demographic profile

\begin{tabular}{|c|c|c|c|c|c|}
\hline & & Frequency & Percent & Valid Percent & $\begin{array}{l}\text { Cumulative } \\
\text { Percent }\end{array}$ \\
\hline \multirow[t]{2}{*}{ Race } & Malays & 439 & 91.5 & 91.5 & 91.5 \\
\hline & Bumiputera & 41 & 8.5 & 8.5 & 100.0 \\
\hline \multirow[t]{5}{*}{ Age } & $51-55$ & 199 & 41.5 & 41.5 & 41.5 \\
\hline & $56-60$ & 134 & 27.9 & 27.9 & 69.4 \\
\hline & $61-65$ & 77 & 16.0 & 16.0 & 85.4 \\
\hline & $66-70$ & 42 & 8.8 & 8.8 & 94.2 \\
\hline & $>71$ & 28 & 5.9 & 5.9 & 100.0 \\
\hline \multirow[t]{2}{*}{ Gender } & Male & 196 & 40.8 & 40.8 & 40.8 \\
\hline & Female & 284 & 59.2 & 59.2 & 100.0 \\
\hline \multirow[t]{4}{*}{ Marital Status } & Never Married & 57 & 11.9 & 11.9 & 11.9 \\
\hline & Married & 376 & 78.3 & 78.3 & 90.2 \\
\hline & Widowed/ Divorcee & 47 & 9.8 & 9.8 & 100.0 \\
\hline & Total & 480 & 100.0 & 100.0 & \\
\hline
\end{tabular}

Based on table 4.1, majority of the respondent is Malays, aged range 51-55, female and married. In depth, Malays respondent consist of $91.5 \%$, whereas Bumiputera respondent is $8.5 \%$. Most of the respondent age range is $51-55$ (41.5\%), followed by $56-60(27.9 \%), 61-65$ $(16 \%), 66-70(8.8 \%)$ and lastly more than 71 years old $(5.9 \%)$. Data distribution of the respondent in term of marital status is divided into 3 categories. Respondent whom never 
married consists of $11.9 \%$, whereas married with living partners is $78.3 \%$, and for widowed or divorced consist of $9.8 \%$ of the total sample.

Table 2: Result for level of wellbeing

\begin{tabular}{lccccc}
\hline & $\mathrm{N}$ & Minimum & Maximum & Mean & Std. Deviation \\
\hline Self-rated Health & 480 & 1.67 & 4 & 3.1408 & 0.45815 \\
Life Satisfaction & 479 & 1.33 & 4 & 3.1479 & 0.47237 \\
Wellbeing & 480 & 1.89 & 4 & 3.1447 & 0.41119 \\
\end{tabular}

From table 4.2, mean of wellbeing is 3.1447. This indicate that the respondent experience slightly medium to high level of wellbeing.

Table 3: Result for differences of employment status with self-rated health

Results for t-test

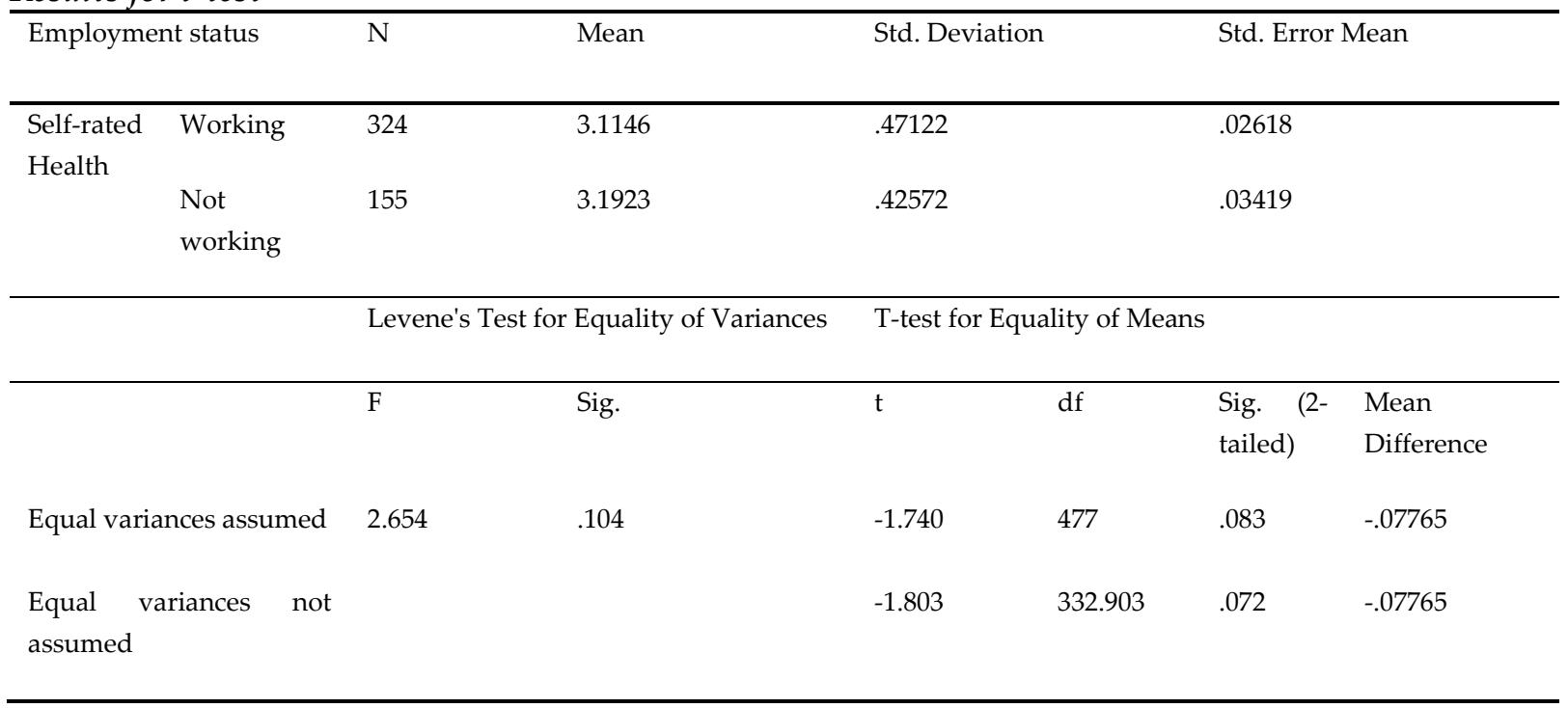

From the result shown on table 4.3, mean for working (employed respondent) is 3.1146 (standard deviation 0.47122), whereas mean for not working respondent (unemployed) is 3.11923 (standard deviation 0.42572 ). The different between the mean is 0.0777 . To decide whether to use equal variance assumed or equal variance not assumed, p-value on Levene's test of equality of variance is checked. In table 4.3, p-value for Levene's test is 0.104 , which is larger than alpha value of 0.05 . Thus, equal variance not assumed will be used to determine the level of self-rated health towards employment statuses (Pallant \& Lee, 2015).According to equal variance not assumed, p-value is 0.072 , which larger than alpha value (0.05). Thus, the results show that, there is no significant different on employment status and self-rated health $[\mathrm{t}(\mathrm{df}=332.903)=-1.083, \mathrm{p}>0.05)$. 
Table 4: Result for differences of employment status with life satisfaction

Results for t-test

\begin{tabular}{|c|c|c|c|c|c|c|c|}
\hline \multicolumn{2}{|c|}{ Employment status } & \multirow{2}{*}{$\begin{array}{l}\mathrm{N} \\
323\end{array}$} & \multirow{2}{*}{$\begin{array}{l}\text { Mean } \\
3.1282\end{array}$} & \multicolumn{2}{|c|}{ Std. Deviation } & \multicolumn{2}{|c|}{ Std. Error Mean } \\
\hline \multirow{4}{*}{$\begin{array}{l}\text { Life } \\
\text { satisfaction }\end{array}$} & Working & & & .47460 & & .02641 & \\
\hline & $\begin{array}{l}\text { Not } \\
\text { working }\end{array}$ & 155 & 3.1911 & .46721 & & .03753 & \\
\hline & & \multicolumn{2}{|c|}{ Levene's Test for Equality of Variances } & \multicolumn{4}{|c|}{ T-test for Equality of Means } \\
\hline & & $\mathrm{F}$ & Sig. & $\mathrm{t}$ & df & $\begin{array}{l}\text { Sig. (2- } \\
\text { tailed) }\end{array}$ & $\begin{array}{l}\text { Mean } \\
\text { Difference }\end{array}$ \\
\hline \multicolumn{2}{|c|}{ Equal variances assumed } & .038 & .845 & -1.362 & 476 & .174 & -.06286 \\
\hline $\begin{array}{l}\text { Equal var } \\
\text { assumed }\end{array}$ & nces not & & & -1.370 & 308.143 & .172 & -.06286 \\
\hline
\end{tabular}

From the result shown on table 4.3, mean for working (employed respondent) is 3.1282 (standard deviation .47460), whereas mean for not working respondent (unemployed) is 3.1911 (standard deviation .46721). The different between the mean is 0.0629 . To decide whether to use equal variance assumed or equal variance not assumed, $p$-value on Levene's test of equality of variance is checked. In table 4.3, p-value for Levene's test is .845 , which is larger than alpha value of 0.05 . Thus, equal variance not assumed will be used to determine the level of life satisfaction towards employment statuses (Pallant \& Lee, 2015). According to equal variance not assumed, p-value is .172, which larger than alpha value (0.05). Thus, the results show that, there is no significant different on employment status and self-rated health $[\mathrm{t}(\mathrm{df}=308.143)=-1.370, \mathrm{p}>0.05)$.

Table 5: Result for level of correlation on voluntarism and Self-rated

Result for Pearson Correlation

Voluntarism Self-rated

Health

\begin{tabular}{llcc}
\hline Voluntarism & Pearson Correlation & 1 & $.522^{* *}$ \\
& Sig. (2-tailed) & & .000 \\
& $\mathrm{~N}$ & 478 & 478 \\
Self-rated Health & Pearson Correlation & $.522^{* *}$ & 1 \\
& Sig. (2-tailed) & .000 & 480
\end{tabular}

**. Correlation is significant at the 0.01 level (2-tailed). 
A Pearson product-moment correlation ( $r$ ) was computed to assess the relationship between the level of involvement in voluntarism activities and level of life satisfaction of elderly. There was a correlation between the two variables $[\mathrm{r}=.522, \mathrm{n}=478, \mathrm{p}=0.000$. Overall, there was a medium, positive correlation between voluntarism activities and life satisfaction. Increase on involving in voluntarism activities were correlated with increases in rating of life satisfaction.

Table 6: Result for level of correlation on voluntarism and life satisfaction Result for Pearson Correlation

\begin{tabular}{llcc}
\hline & Voluntarism & Life Satisfaction \\
\hline Voluntarism & Pearson Correlation & 1 & $.664^{* *}$ \\
& Sig. (2-tailed) & & .000 \\
$\mathrm{~N}$ & 478 & 478 \\
Life Satisfaction & Pearson Correlation & $.664^{* *}$ & 1 \\
& Sig. (2-tailed) & .000 & 479
\end{tabular}

**. Correlation is significant at the 0.01 level (2-tailed).

A Pearson product-moment correlation ( $r$ ) was computed to assess the relationship between the level of involvement in voluntarism activities and level of life satisfaction of elderly. There was a correlation between the two variables $[\mathrm{r}=0.478, \mathrm{n}=478, \mathrm{p}=0.000$. Overall, there was a medium, positive correlation between voluntarism activities and life satisfaction. Increase on involving in voluntarism activities were correlated with increases in rating of life satisfaction.

\section{DISCUSSION}

Based on the result obtained, the research concludes that the overall level of respondent wellbeing is high. The findings also found out that voluntarism correlates with the level of life satisfaction as well as self-rated health. These outcomes consistent with recent research by Pillemer et al. (2017). They found that recruited individual toward participating in voluntary program suggest positive outcomes from their involvement. In another major study, the degree of life satisfaction with voluntarism has shown to be an important predictor of older volunteers' perception of wanting to be happy (Dulin, Gavala, Stephens, Kostick, \& McDonald, 2012).

However, the respondent employment status does not show significant different toward life satisfaction and self-rated health. Type of paid work that respondent engage to might become the factors of the results. This is based on previous research by (Schibye, Hansen, Søgaard, \& Christensen, 2001).Additionally, the demographic factor might influence the overall environment of the respondents. Other factor such as helping a spouse or family members with activities of daily living reduced the chances of returning to work (Gonzales, Lee, \& Brown, 2017) 
Therefore, family members, local authority as well as policy makers should take advantage on how voluntarism can enhance elderly wellbeing. Consequently, responsible party should aware that the elderly are less likely to engage themselves in employment attachment as it might bring out the negative effect.

\section{REFERENCES}

Akintayo, T., Häkälä, N., Ropponen, K., Paronen, E., \& Rissanen, S. (2016). Predictive factors for voluntary and/or paid work among adults in their sixties. Social Indicators Research, 128(3), 1387-1404. doi: 10.1007/s11205-015-1084-5

Alatartseva, E., \& Barysheva, G. (2015). Well-being: Subjective and objective aspects. Procedia - Social and Behavioral Sciences, 166, 36-42. doi: http://dx.doi.org/10.1016/j.sbspro.2014.12.479

Au, A. M. L., Chan, S. C. Y., Yip, H. M., Kwok, J. Y. C., Lai, K. Y., Leung, K. M., et al (2017). Age-friendliness and life satisfaction of young-old and old-old in Hong Kong. Current Gerontology and Geriatrics Research, 2017, 10. doi: 10.1155/2017/6215917

Bakar, A. A., Osman, M. M., Bachok, S., \& Ibrahim, M. (2016). Investigating rationales of Malaysia quality of life and wellbeing components and indicators. Procedia-Social and Behavioral Sciences, 222, 132-142.

Baker, L. A., Cahalin, L. P., Gerst, K., \& Burr, J. A. (2005). Productive activities and subjective well-being among older adults: The influence of number of activities and time commitment. Social Indicators Research, 73(3), 431-458. doi: 10.1007/s11205-005-0805-6

Dodge, R., Daly, A. P., Huyton, J., \& Sanders, L. D. (2012). The challenge of defining wellbeing. International Journal of Wellbeing, 2(3).

Dulin, P. L., Gavala, J., Stephens, C., Kostick, M., \& McDonald, J. (2012). Volunteering predicts happiness among older Māori and non-Māori in the New Zealand health, work, and retirement longitudinal study. Aging \& mental health, 16(5), 617-624.

Gilmour, H. (2012). Social participation and the health and well-being of Canadian seniors. Health Reports, 23(4), $23-32$.

Gonzales, E., Lee, Y., \& Brown, C. (2017). Back to work? Not everyone. Examining the longitudinal relationships between informal caregiving and paid work after formal retirement. Journals of Gerontology - Series B Psychological Sciences and Social Sciences, 72(3), 532-539. doi: 10.1093/geronb/gbv095

Haub, C. (2011). World population aging: clocks illustrate growth in population under age 5 and over age 65. Population Reference Bureau.

Herzog, A., House, J. S., \& Morgan, J. N. (1991). Relation of work and retirement to health and well-being in older age. Psychol Aging, 6. doi: 10.1037/0882-7974.6.2.202

Hilbrecht, M., Lero, D. S., Schryer, E., Mock, S. E., \& Smale, B. (2017). Understanding the association between time spent caregiving and well-being among employed adults: testing a model of work-life fit and sense of community. Community, Work \& Family, 20(2), 162-180. doi: 10.1080/13668803.2015.1112254

Kim, B., Park, S., \& Antonucci, T. C. (2016). Longitudinal changes in social networks, health and wellbeing among older Koreans. Ageing \& Society, 36(9), 1915-1936.

Lee, J., \& Kim, M.-H. (2017). The effect of employment transitions on physical health among the elderly in South Korea: A longitudinal analysis of the Korean Retirement and Income Study. Social Science E Medicine, 181, 122-130. doi: https://doi.org/10.1016/j.socscimed.2017.04.002

Maimaris W, Hogan H, \& Lock, K. (2010). The impact of working beyond traditional retirement ages on mental health: Implications for public health and welfare policy. Public Health Reviews, 32,532-48.

Malanina, V. A., Frolova, E. A., \& Lei, H. (2017). Social and Economic Activity of the Elder Generation in Tomsk Region. The European Proceedings of Social \& Behavioural Sciences (EpSBS). Vol. 19: Lifelong Wellbeing in the World (WELLSO 2016). - Nicosia, 2017., 192016, 217-222.

McMunn, A., Nazroo, J., Wahrendorf, M., Breeze, E., \& Zaninotto, P. (2009). Participation in socially-productive activities, reciprocity and wellbeing in later life: baseline results in England. Ageing Soc, 29. doi: 10.1017/s0144686x08008350

McNaught, A. (2011). Defining wellbeing. Understanding wellbeing: An introduction for students and practitioners of health and social care, 7-23. 
Musick, M. A., Herzog, A., \& House, J. S. (1999). Volunteering and mortality among older adults: findings from a national sample. J Gerontol B Psychol Sci Soc Sci, 54B. doi: 10.1093/geronb/54B.3.S173

Mutchler, J. E., Burr, J. A., \& Caro, F. G. (2003). From paid worker to volunteer: Leaving the paid workforce and volunteering in later life. Social forces, 81(4), 1267-1293.

Nawi, N. R. C., Asmuni, A., \& Pendidikan, F. P. (2013). Motivasi sukarelawan terhadap penglibatan dalam kerja sukarela di Yayasan Salam Malaysia. In Dalam Seminar Pasca Siswazah dalam Pendidikan (GREDUC 2013).

Oman, D., Thoresen, C. E., \& McMahon, K. (1999). Volunteerism and mortality among the community-dwelling elderly. Journal of Health Psychology, 4. doi: 10.1177/135910539900400301

Pallant, A., \& Lee, H.-S. (2015). Constructing scientific arguments using evidence from dynamic computational climate models. Journal of Science Education and Technology, 24(2-3), 378-395.

Pillemer, K., Wells, N. M., Meador, R. H., Schultz, L., Henderson, J. C. R., \& Cope, M. T. (2017). Engaging Older Adults in Environmental Volunteerism: The Retirees in Service to the Environment Program. The Gerontologist, 57(2), 367-375. doi: 10.1093/geront/gnv693

Pozzi, M., Marta, E., Marzana, D., Gozzoli, C., \& Ruggieri, R. A. (2014). The Effect of the Psychological Sense of Community on the Psychological Well-Being in Older Volunteers (Vol. 10).

Ruiz, E. M., Marcos-Matás, G., \& Tornero, M. E. M. (2016). Older volunteers' intention to remain in service in nonprofit organisations. Psicothema, 28(3), 272-277. doi: 10.7334/psicothema2016.20

Sabbath, E. L., Matz-Costa, C., Rowe, J. W., Leclerc, A., Zins, M., Goldberg, M., et al. (2016). Social predictors of active life engagement: a time-use study of young-old french adults. Research on aging, 38(8), 864-893.

Sarracino, F. (2010). Social capital and subjective well-being trends: Comparing 11 western European countries. The Journal of Socio-Economics, 39(4), 482-517.

Schibye, B., Hansen, A. F., Søgaard, K., \& Christensen, H. (2001). Aerobic power and muscle strength among young and elderly workers with and without physically demanding work tasks. Applied Ergonomics, 32(5), 425-431. doi: https://doi.org/10.1016/S0003-6870(01)00034-5

Schmiedeberg, C., \& Schröder, J. (2017). Leisure activities and life satisfaction: An analysis with German panel data. Applied Research in Quality of Life, 12(1), 137-151.

Shah, K. N., Lin, F. V., Yu, F., \& McMahon, J. M. (2016). Activity engagement and physical function in old age sample. Archives of Gerontology and Geriatrics, 69, 55-60. doi: 10.1016/j.archger.2016.11.007

Sone, T., Nakaya, N., Ohmori, K., Shimazu, T., Higashiguchi, M., Kakizaki, M., et al (2008). Sense of life worth living (ikigai) and mortality in Japan: Ohsaki Study. Psychosomatic Medicine, 70(6), 709-715.

Staudinger, U. M., Finkelstein, R., Calvo, E., \& Sivaramakrishnan, K. (2016). A Global View on the Effects of Work on Health in Later Life. The Gerontologist, 56(Suppl_2), S281-S292. doi: 10.1093/geront/gnw032

Thoits, P. A., \& Hewitt, L. N. (2001). Volunteer work and well-being. Journal of health and social behavior, 115131.

Van Willigen, M. (2000). Differential benefits of volunteering across the life course. The Journals of Gerontology Series B: Psychological Sciences and Social Sciences, 55(5), S308-S318.

WHO. (2015). World report on ageing and health: World Health Organization.

Zhang, W., Feng, Q., Lacanienta, J., \& Zhen, Z. (2017). Leisure participation and subjective well-being: Exploring gender differences among elderly in Shanghai, China. Archives of Gerontology and Geriatrics, 69, 45-54. doi: 10.1016/j.archger.2016.11.010 